УДК 069.5:316.75(497.1)"196/197";

725.91:316.75(497.1)"196/197"

Olga MANOJLOVIĆ PINTAR, Ph. D. Aleksandar IGNJATOVIC, Ph. D.

\title{
CATALYSTS OF INTRICATE IDENTITIES: THREE BELGRADE MUSEUMS IN SOCIALIST YUGOSLAVIA*
}

\begin{abstract}
The article explores the position and role of the three museums conceptualized and built during the period of socialist Yugoslavia, which greatly influenced the process of collective identity making during the 1960 s and 1970s.
\end{abstract}

Key words: the Museum 25th May, the Museum of Contemporary Art, the Museum of African Art, socialist Yugoslavia, identity

\section{Introduction}

In September 2011, during the reconstruction of the interior of the Museum of Yugoslav History in Belgrade, an interesting mural was discovered beneath the thick layer of mortar. It represented a map of the world, rendered in a somewhat abstract manner, which affronted the public gleaming in white and gold. The mural was an integral part of the Museum $25^{\text {th }}$ May, which had been housed in the same building prior to the establishment of the Museum of Yugoslav History in 1996. For four decades, it occupied a prominent place in the museum's interior. Subsequently, after institutional renaming and reorganization, the map was whitewashed and removed from the eyes of the public. ${ }^{1}$

This article is the result of the work on the projects Tradicija i transformacija istorijsko nasleđe i nacionalni identiteti u Srbiji u XX veku(№ 47019), and Srpska umetnost XX veka - nacionalno i Evropa (№ 177013), financed by the Ministry of Education, Science and the Technological Development of the Republic of Serbia.

1 As one of the key museums built in Socialist Yugoslavia, the Museum 25 May had been associated with founding narratives of the country, representing a benchmark of the symbolic urban, ideological and political topography of the capital city. Ceremonially opened in 1962, this Museum was established in order to keep 
During the existence of the Museum 25 May, the map represented a proper context for framing the collection of this peculiar institution, depicting the world's continents, neatly named, outlined in white and surrounded by a golden-brownish mass as a representation of the Globe's oceans. The map was dotted with golden labels, marked with years that corresponded to Tito's visits to the countries of Europe, Asia, Africa and North America. Such a remarkable figurative list of the Yugoslav president's journeys was completed by the year of 1962, when the Museum ceremonially opened its door, being an outstanding edifice which architectural concept came out of the particular ferment of ideas associated with Yugoslav Socialist modernism. ${ }^{2}$ Unquestionably aimed at visualizing and presenting President Tito's diplomatic journeys at the peak of his political career, the map was open to further inscriptions (even though it has been cut off on the Equator and consisted of the globe's northern hemisphere only). It clearly marked not only the current country's position between the communist and capitalist worlds - which was on the rise particularly after the first Conference of Non-Aligned countries held in Belgrade in 1961 - but also its future prospects.

From today's perspective, the map seems intriguingly evocative: glittering gold and white stood more for a transcendent world without political boundaries and borders, than for an standard imagery of the world's divided political actualities. The narrative framed within the map speaks of an imaginative territory, which was not, as of any other map, simply charted. Instead, it represents a system of signs structured by codes of understanding which speaks for a space imagined, in the same fashion as history speaks for time ${ }^{3}-$

and display the gifts, which Josip Broz Tito had received from international politicians and public figures as well as from Yugoslav citizens. Maintaining and publicly presenting various artifacts, along with President Tito's personal documents and the Archive of the Presidential Cabinet, the Museum became one of the most recognizable cultural institutions of the 1960 s and 1970s. At the same time, it was more than instrumental in constructing a distinctly Yugoslav concept of cultural and political identity that had already started to crystallize in the previous decade. Смрт у трезору, Каталог изложбе 27/06/09 - 23/08/09, Музеј историје Југославије, Београд, 2009.

2 For the museum building and its functions in the political landscape of the socialist Yugoslavia see: Aleksandar Ignjatović, "Otvaranje i popularizacija: Muzej 25. maj i transformacija prostora Dedinja", in: Olga Manojlović Pintar, Mile Bjelajac, Radmila Radić (eds), Tito - viđenja i tumačenja, Institut za noviju istoriju Srbije i Arhiv Jugoslavije, Beograd, 2011, pp. 601-614; Dijana Milašinović Marić, Vodič kroz modernu arhitekturu Beograda, Društvo arhitekata Beograda, Beograd, 2002, p. 112; Branko Vujović, Beograd u prošlosti i sadašnjosti, Draganić, Beograd, 1994, p. 280.

3 On complex relations between time, history and representation see: Lynn Hunt, Measuring Time, Making History, CEU Press, Budapest and New York, 2008; Noël Carroll, "Interpretation, History and Narrative", in: Geoffrey Roberts (ed.), The History and Narrative, Routledge, London, 2001, 246-265; Jörn Rüsen, "New Direction in Historical Studies", in: idem, Studies in Metahistory, Human Sciences Research Council, Pretoria, 1993, pp. 203-219; See also: Jörn Rüsen 
it does not reflect, but rather construct an image of the past and consequently of the present. ${ }^{4}$ The map indeed symbolized the contemporaneous self-perception of Yugoslavia as having a mediatory role in a politically divided world. At the same time, it reflected the understanding of the same world as a remote realm wrapped in distant space and time which, with the passage of time and symbolic "conquests" by President Tito, came to be closer to Yugoslav citizens. The map, along with the museum, could be reckoned as a classical showcase of political and cultural creation, a vivid tool of ideological self-promotion. It may also be read as a reflection of the recognizable attempt to create a new vision of the world, which would frame a new identity of the Yugoslavs.

With the dissolution of the Socialist Federal Republic of Yugoslavia in 1991, the map, the museum and the world they had symbolized were irreversibly altered, mutilated and consequently obliterated from the public realm. Simultaneously, many questions have arisen - concerning not only the historical roles and significance of this particular institution, but also of many other museums, once central to the identity of Socialist Yugoslavia. In that sense, the example of the Museum $25^{\text {th }}$ May allows for a possibility to discuss a number of important questions: What was the position - either ideological or political - of state sponsored museums and their collections and exhibitions in Socialist Yugoslavia? How did museums influence the country's self-representation and perception in the public discourse? Last but not least, how did the museums' network either create new or change or enhance existing historical narratives that were important for the imagination of the crucial ideological underpinnings of peculiarly Yugoslav variant of socialism?

In this article we will explore a complex process of collective identity construction as conceptualized and facilitated by Belgrade's three museums inaugurated in the 1960s and 1970s: the above mentioned Museum 25th May (1962), the Museum of Contemporary Art (1965), and the Museum of African Art (1977). We tend to comprehend these institutions, their curatorial and exhibiting practice, as well as their broader social, ideological and political significance not merely as an example of the specific museum institutions of Socialist Yugoslavia built for a purpose in the country's capital. Rather, we aim to explore these museological institutions as telling examples of a vision of identity that seems crucial for our understanding of the historical heritage of Yugoslavia. We will be exploring how these museums comprised a narrative of a country which was imagined not only as a highly peculiar, self-propelled socialist society standing at the crossroads of and straddling the Cold War divide,

(ed.), Meaning and Representation in History, Berghahn Books, Oxford, 2008. On the political invention of historical continuity see: Larry Wolff, The Idea of Galicia: History and Fantasy in Habsburg Political Culture, Stanford University Press, 2010.

See: Denis Wood, The Power of Maps, The Guilford Press, New York, 1992. 
but also how these museums affected the simultaneously coexisting different social, national, and supra-national identities of the Yugoslavs. In spite of the fact that these three museums have not been usually considered the most important cultural institutions either in the Socialist Republic of Serbia or in Yugoslavia, they enormously contributed to the concept of a rather complex collective identity that probably represents a key issue in understanding the country's political, social and cultural history in the period of our concern.

\section{Politics of representation}

Although significantly influencing and supporting the official Yugoslav historical narrative, none of the listed museums was a historical museum itself. The Museum $25^{\text {th }}$ May represented an intricate combination of a documentary and archival institution, and curious treasury of art and ethnology-related objects; the Museum of Contemporary Art was more-or-less exclusively an art museum, while the Museum of African Art merged different focuses on what could be described as contemporary art and anthropology. In addition, all three museums differed as regards to their official institutional founders - the first being founded by the act of capital city's assembly, ${ }^{5}$ the second established solely by the Socialist Republic of Serbia, whilst the third museum represented an outcome of a joint venture between a private collector, the Ethnographic Museum and the City of Belgrade. ${ }^{6}$ Despite being unrelated in a strict sense of thematic, con-

5 Historical Archives of Belgrade, The Peoples' Council of the City of Belgrade, Records of the Council 27-30. 1962, No 1043/i. The Peoples' Council of the City of Belgrade, on the $15^{\text {th }}$ and $27^{\text {th }}$ session of the Council, as well as on the $17^{\text {th }}$ and $30^{\text {th }}$ session of the Board of Producers held on May 26, 1961 and May 4, 1962, respectively made a decision on the establishment of the Museum $25^{\text {th }}$ May. The decision was held in accordance with: Articles 2 and 9 of the Law of Museums (Službeni glasnik Narodne republike Srbije, no. 4/51), Articles 5-8 of the Law of the Management of Cultural, Educational, Artistic and Scientific Institutions (S/užbeni glasnik Narodne republike Srbije, no 57/55), as well as Article 57 of the Law of People's County Councils. Article no. 3 on the basis of which the regulatory act declared that the "aim of the museum is to collect, preserve, explore and exhibit all the gifts (material and non material cultural products) which were presented, dedicated or in any other way related to Marshal Josip Broz Tito and his prolific statesman and personal career in Belgrade - the capital of the Federal People's Republic of Yugoslavia, particularly those artifacts which are related to Tito's contact with Yugoslav citizens and the representatives of social, political, economic and other organizations and workers' associations of our country that participate in the building of socialism and the development of socialist society, as well as cultural testimonies of foreign delegations and statesmen who have visited our country in order to reinforce international cooperation, good neighborly relations, campaign against colonialism, the development and broadening of the policy of active peaceful coexistence and the struggle for peace in the world."

6 Historical Archives of Belgrade, Executive Council of the City of Belgrade Assembly, Decisions and Resolutions, IS 16. 5. 1977. "The Executive Council of the 
ceptual and institutional framework, all three museums represented the paradigmatic examples of identity-construction process, in which the entire museum network in Yugoslavia was structurally included. In that sense, the concept of identity that these institutions produced and disseminated in the public space was neither specifically related to museums only - nor to these museums in particular. This identity concept corresponded to a much deeper, more encompassing and historically more relevant processes of national identification, social structuring and imagination, as well as political legitimization in Socialist Yugoslavia of the 1960 s and 1970s. ${ }^{7}$

All three institutions were highly authentic and instrumental as regards collections, policies, scopes and structure and all three were included into the cultural politics of the socialist Yugoslavia. ${ }^{8}$ Cold War realities influenced substantially its construction as well as the dynamic internal politics, which was marked by the continuous competition of the numerous social and political agents. In this process, different modes of creating and displaying historical narratives varied, being spanned between what could be called two main identity paradigms. The first was of continuity and longevity, which established the idea of exceptionality and uniqueness of the nation/society creating historical continuities through centuries and regions. The

Belgrade Assembly, according to Article 5 of the Decision about the Jurisdiction of the Executive Council and the City Administration for the Performance of Certain Tasks (Službeni list grada Beograda, no. 5/75), as well as Article 25 of the City of Belgrade Budget Decision (Službeni list grada Beograda, no. 25/76), made a decision on the financing the Ethnographic Museum in Belgrade with the sum of 500,000 Dinars, on behalf of the City of Belgrade, which was to be used for the establishment of the Museum of African Art".

7 Extensive discussions on museums as important institutions of culture in socialist Yugoslavia started from the beginning of its existence and reached its climax during and after the breakup with the Kominform in July 1948. State and party commissions were meticulously discussing museum position and role in the politically and ideologically specifically defined state and the society. See: Mihajlo Panić Surep, O potrebi preuređenja naših muzeja i postavljanju linije njihovog daljeg razvitka, in: Muzeji, no. 2, 1949, pp. 53-60.

One of the first decisions of the Ministry of Science and Culture concerned the formation of the Department for Culture and Arts which defined thematic structure of the regional museums including socialist development of the region into the historical perspective. Reorganizacija naših muzeja, in: Muzeji, 3-4, 1949, pp. 1-10. Three years later, question of the ideological contents of the museum exhibitions was discussed by the Expert Committee Marking the Historic Sites and Activities Reviving Historical Events of the Peoples Liberating War. This commission was formed as a professional body of the Central Committee of the Federation of the Associations of National Liberation War Veterans. Archives of Yugoslavia, Fond SUBNOR AJ, 297-81.

8 On cultural politics of socialist Yugoslavia see: Miško Šuvaković, Istorija umetnosti u Srbiji XX vek, II Orion Beograd, 2012; Radina Vučetić, Koka-kola socijalizam: amerikanizacija jugoslovenske popularne kulture šezdesetih godina XX veka, Službeni glasnik, Beograd, 2012; Goran Miloradović, Lepota pod nadzorom, Sovjetski kulturni uticaji u Jugoslaviji 1945-1955, Institut za savremenu istoriju, Beograd, 2012. 
second paradigm was of bridging identity, which agitated for public space as a specific tool in the ideologically and politically instrumental bridging of various cultures and political realities. While exhibiting and representing cultural heritage, these cultural institutions were actively taking part in the ideological construction of identities and in the ongoing process of spatialization of political power, reinforcing some of the crucial foundation ideas of the Yugoslav society, such as uniqueness and cultural and political mediation.

\section{Mediation of Diversities: The Museum 25 ${ }^{\text {th }}$ May}

The Museum 25th May had a rather curious history of inauguration that was held on the May $25^{\text {th }}, 1962$, as a gift of the Belgrade municipality to President Tito on the occasion of his seventieth birthday. It was erected in order to preserve gifts received from international politicians, eminent public figures, numerous Yugoslav citizens, political organizations, diverse companies and unions. Not only the museum's aforementioned collection, which was considered unique in its diversity of objects and displays, but also the building itself and the social and political context in which the same institution was operating, clearly represented Yugoslavia's intricate cultural politics of the period. The building was designed by Mihailo Janković, an outstanding architect and the author of several important buildings in socialist Belgrade (such as Federal Executive Council (1954-1962) and Building of Social and Political Organizations (1959-1964), both in the New Belgrade) as a standard example of modernist architecture of the 1960s that was gaining popularity conspicuously representing Yugoslavia's political course. ${ }^{9}$ Erected on a vast plateau bordered by a meticulously landscaped park, its vivid architectural transparency and the minimalism of the details, along with the entrance portico which was imagined to represent the end of the long, stepped promenade flanked by greenery, could be read as a symbolic image and in the same time as the founding stone of Yugoslav politics and culture. The openness and lightness of the design might have corresponded to what was seen as an essential feature of Yugoslav society, which had acquired its own version of both socialism and democracy. ${ }^{10}$ Situated

9 For architecture of the Museum 25th May see: A. Ignjatović, op. cit.; for architecture of Socialist Yugoslavia see: Vladimir Kulić et al., Modernism in Between: The Mediatory Architectures of Socialist Yugoslavia, Jovis, Berlin, 2012.

10 On the relationships between architectural culture and Yugoslav social democracy see: Aleksandar Ignjatović, "Out of the Sands, to Span the Future: The Architectural Image of Yugoslav Socialism in Belgrade", Centropa, vol. 13, no. 1, January, 2013, pp. 49-63; Aleksandar Ignjatović, "Tranzicija i reforme: arhitektura u Srbiji 1952-1980", in: Miško Šuvaković, Nevena Daković, Aleksandar Ignjatović, Vesna Mikić, Jelena Novak i Ana Vujanović (eds), Istorija umetnosti u Srbiji XX vek. Realizmi i modernizmi oko Hladnog rata, Orion Art i Katedra za muzikologiju Fakulteta muzičke umetnosti, Belgrade, 2012, pp. 689-710. See also: V. Kulić, op. cit. 
on the edge of Tito's own residence - on the very border between the private realm of the Yugoslav leader and the greened, open public park - the museum stressed not only the idea of the mutual penetration of the exhibition and its immediate surroundings, but also the complex realm of political authority in Yugoslav self-managing socialism.

More than to its modernist architecture, the museum was credited with having the enormous influence through the practice of presenting gifts to President Tito, which was continually taking place throughout the year and reaching its climax on the May Day celebrations. It was during this particular month, which importantly bore the archetypal symbolism of spring and youth - the political symbolism "of renewal, growth, hope and joy"11 - that the holiday of Tito's birthday was established as one of the ideological pillars of socialist Yugoslavia. ${ }^{12}$ More than any other public holiday, the celebration of May $25^{\text {th }}$ exuded a special aura of the President's direct and immediate contact with people and of an emotional bondage between the political leader and the citizens. Thus, the celebrations of Tito's birthday in addition to festivities at other two public holiday regularly held in May, "combined public and private merry-making and good cheer with the assertion of loyalty to the movement". ${ }^{13}$ With the annual repetition of the May Day performances in which the whole society was to be involved, the imagined cross-national, cross-cultural and class unification was achieved in the public space with the museum as its focal point. ${ }^{14}$

The celebration timetable, which for weeks ahead defined the schedule and the kind of reception given to hundreds of gift-givers,

11 Eric Hobsbawm, „Mass-Producing Traditions: Europe, 1870-1914", in: Eric Hobsbawm, Terence Ranger (eds), The Invention of Tradition, Cambridge University Press, Canto, Cambridge, 1997, p. 284.

12 See: Olga Manojlović Pintar, Ideološko i političko u spomeničkoj arhitekturi Prvog i Drugog svetskog rata na t/u Srbije, PhD Thesis (University of Belgrade, Faculty of Philosophy, 2004), pp. 222-225; Bojana Vikedanic, "First and Last Emperor: Representations of the President, Bodies of the Youth", in: Breda Luthar and Maruša Dušnik (eds), Remembering Utopia: The Culture of Everyday Life in Socialist Yugoslavia, New Academy Publishing, Washington, DC, 2010, pp. 37-64; Tone Bringa, "The Peaceful Death of Tito and the Violent End of Yugoslavia", in: John Bourneman (ed.), Death of the Father. An Anthropology of the End in Political Authority, Berghahn, Oxford, 2004, pp. 148-200 (esp. 156-157). On a quasi-religious dimension of the May $25^{\text {th }}$ celebrations see: Marijana Belaj, "'I'm not religious, but Tito is a God': Tito, Kumrovec, and the New Pilgrims", in: Peter Jan Margerey (ed.), Shrines and Pilgrimage in the Modern World, Amsterdam University Press, Amsterdam, 2008, pp. 71-94.

13 Eric Hobsbawm, ibid, p. 286. Namely, two international holidays were regularly celebrated in socialist Yugoslavia: the International Workers' Day (May 1) and the Victory Day (May 9 ).

14 The Tito Effect, Charisma as Political Legitimacy, Museum of Yugoslav History, Belgrade, 2009. 
testified that the presentation of gifts was both politically and socially acceptable and expected form of behavior. ${ }^{15}$ Among the thousands of gifts, the ceremonial baton - the so-called Youth Baton - was the most recognizable symbol of the whole practice; up until the late 1980 s, the museum itself had acquired more than 22,000 of these objects. ${ }^{16}$ Namely, every year since the end of the Second World War up to 1987, mass baton relays were carried out throughout Yugoslavia, drafting a unique mental map in which multiple Yugoslav identities were symbolically charted. Millions of bodies in motion, holding batons in the ceremonial rallies, were meant to represent a vivid expression of social and national bondage, mediation and a metaphor for a dynamic society. Even though all the batons were dedicated to Josip Broz Tito, after the death of Stalin, Yugoslav communists as the loudest critics of personality cult introduced remarkable changes in Tito's birthday celebrations. Renaming the holiday of May $25^{\text {th }}$ (Tito's own birthday) into Youth Day was an unambiguous attempt to affirm and reinforce new political realities. Between 1957 and 1980, Tito regularly received Youth batons at a major Youth rally, held at the Yugoslav People's Army stadium in Belgrade - the place visually and meaningfully connected to the neighboring Museum $25^{\text {th }}$ May. ${ }^{17}$

State and party officials believed they were creating a specific form of social empathy among Yugoslav citizens through the process of gift-giving to the President. Usual presenters of gifts were diverse public institutions: schools, hospitals, work organizations, sports associations, factories, mines and peasant working cooperatives. ${ }^{18}$ Thus, the authenticity of the Yugoslav self-management practice based on a broad network of workers' councils as active subjects of society was both constructed and affirmed.

15 On ideological, political and social significance of gift-giving see the classical essay: Marcel Mauss, The Gift: forms and functions of exchange in archaic societies. Routledge, London, 1990 (1922); Bronislaw Malinowski, "The Principle of Give and Take", in: Aafke E. Komter (ed.), The Gift. An Interdisciplinary Perspective, Amsterdam University Press, Amsterdam, 1996, pp. 15-18. See also: Cele Otnes and Richard F. Beltramini, "Gift Giving and Gift Giving", in: Cele Otnes and Richard F. Beltramini (eds), Gift-Giving. A Research Anthology, Bowling Green State University, Bowling Green, OH, 1996, pp. 3-18; Barry Schwartz, "The Social Psychology of the Gift", in: Aafke E. Komter (ed.), The Gift. An Interdisciplinary Perspective, Amsterdam University Press, Amsterdam, 1996, pp. 69-80.

16 Titova štafeta, Štafeta mladosti, 1945-1987, Katalog izložbe, Muzej istorije Jugoslavije, Beograd, 2008.

17 Interestingly, the stadium was an early work by the same architect, Mihailo Janković (working together with Kosta Popović), and was built between 1947 and 1951 as the Yugoslav People's Army Stadium, one of the most ambitious designs of the time.

18 On gift-giving practices in the context of the culture of Socialist Yugoslavia, especially regarding to the Youth Baton see: Bojana Vikedanic, "First and Last Emperor: Representations of the President, Bodies of the Youth", in: Breda Luthar and Maruša Dušnik (eds), Remembering Utopia: The Culture of Everyday Life in Socialist Yugoslavia, New Academy Publishing, Washington, DC, 2010, pp. 37-64. 


\section{Between the Two Worlds: The Museum of Contemporary Art}

The Museum of Contemporary Art was founded in 1955 (under the original name the Modern Gallery that had remained until 1965), after the original initiative of the Council for Art and Education of Serbia, which dates back in $1951 .{ }^{19}$ Although being initiated, built, and financed solely by the Republic of Serbia, the museum originally had an ambitious aim to "represent and follow the development of modern Yugoslav art from its origin at the beginning of this century, with the emphasis on its present aspect". ${ }^{20}$ Most of the members of the Council were well-established artists and notable intellectuals, all from Serbia. ${ }^{21}$ It was only in 1959, after several years of working on the future museum's program and policy, that the Council proposed a final concept of the future museum, which was accepted by the Council for Culture of Serbia and the Council for Culture of the City of Belgrade. This led first to the decision to officially found the museum and erect the building between 1960 and 1965. In October 1965, on the twentieth-first anniversary of the liberation of Belgrade, the museum was ceremonially opened in New Belgrade, displaying the best pieces from its collection that had by that time numbered more than 3,500 artifacts. The inauguration speeches were delivered by Branko Pešić and Aleksandar Ranković, who stressed that the museum was not only a "panorama of the Serbian and Yugoslav art of the twentieth century", but it also represents a "home of brotherhood and unity, of beauty and mutual cooperation". ${ }^{22}$ The ideological rationale of the museum was further reinforced by the constantly repeated words of its director and spiritus movens, art critic and artist Miodrag B. Protić, that the museum was to become an "instrument of socialization", whilst art exhibited in it should have the aim not only of bonding people but also of "cultivating the spirit of tolerance". ${ }^{23}$ At the same

19 In 1955, the Council for Art and Education of Serbia established the Council for Modern Gallery and four years later yet another board in charge with setting up the program for the future museum's building. It was only in 1965, immediately before the construction works were completed, that the Council for Modern Gallery changed the official name of the gallery into the Museum of Contemporary Art. The Archives of the Museum of Contemporary Art, Decision of the Gallery Council no. 01-28/1, 22. 3. 1965. See also: Miodrag B. Protić, "Museum of Modern Art in Belgrade. History and Reasons of Foundation, and General Concept", in: Miodrag B. Protić (ed.), Muzej savremene umetnosti, Muzej savremene umetnosti, Beograd, 1965.

20 Ibid., p. 214.

21 The original members of the Council (as appeared in the original foundation act) were: Stanka Veselinov (who was the Council's President), Miodrag B. Protić (Secretary of the Council), Veljko Petrović (then the Director of the National Museum in Belgrade), Peđa Milosavljević, Oto Bihalji Merin, Dobrica Ćosić, Vlado Madžarić, Milo Milunović, Milivoj Nikolajević, Svetozar Radojčić, Sreten Stojanović and Petar Lubarda.

22 "Otvorena kuća lepote i stvaralaštva", Večernje novosti, 21. 10. 1965.

23 Miodrag B. Protić, "Praznik kulture, znamen epohe”, Borba, 21. 10. 1965. 
time, public discourse was permeated by similar messages about social and political importance of the museum, which was believed to have been epitomized "not only the beauty of contemporary Yugoslav art, but also the authentic monument of history". ${ }^{24}$

It was with this ideological burden that the museum started its activities and in the first phase of the development, which lasted until the mid 1980s, its permanent collection encompassed what was thought of as Yugoslav art of the twentieth century, organized exclusively by the temporal scope: the First (1900-1918); the Second (1918-1941) and finally, the Third Period (after 1945). The names of the collections clearly embodied the evolutionary concept of constant development and outlined the vision of Yugoslav art as a historically evolving phenomenon. Furthermore, the structure of the museum's collection was based on a set of mutually interdependent principles. According to the museum's director Miodrag B. Protić, the "exhibited works should display modern Yugoslav art from its origins up to the present day"; besides that, the policy of the museum declared that the display should be presented as an "organic whole", as being evolutionary developed. At the same time, the whole display ought to represent a "dialectical concept of history", whilst the collections were distinguished by the idea of "authenticity" of each of the individual artifacts displayed. ${ }^{25}$ It is beyond doubt that such an interpretation that reflected an ideological formula pursued by the Yugoslav political and intellectual elite of the time, corresponded to overall decentralization, the federalist concept of the state and a vision of a supra-national Yugoslav identity.

The concept that underlined the museum's central narrative was nevertheless, more complex and ramified. Firstly, it was based on progressivism as a principle that permeated and governed the ideological discourse of socialist Yugoslavia, which was constantly reforming itself over the course of the 1960s and 1970s. The position of art as a discourse in such a context was fundamentally important as it represented, according to the words of the museum's director, a "Symbol of the epoch and society, eager to ascend into the future". ${ }^{26}$ Secondly, the museum encapsulated a vision of the Yugoslav nation in accordance with the ideology of socialist patriotism and the "brotherhood and unity", in which the Serbian cultural and national identity were considered part of a broader Yugoslav identity. The narrative comprised an intricate idea that legitimized broader political process-

24 "Muzej savremene umetnosti - praznik jugoslovenske kulture", Duga, 26. 12. 1965.

25 Miodrag B. Protić, "Museum of Modern Art in Belgrade. History and Reasons of Foundation, and General Concept", in: Miodrag B. Protić (ed.), Muzej savremene umetnosti, Muzej savremene umetnosti, Beograd, 1965, pp. 214-215.

26 Miodrag B. Protić, "Istorijat Muzeja savremene umetnosti", in: Miodrag B. Protić (ed.), Muzej savremene umetnosti, Muzej savremene umetnosti, Beograd, 1965, p. 4. 
es in the country that was constantly moving towards decentralization and federalization, either in the sphere of governmental issues, in culture or in the society. Representing peaks of entire Yugoslav art, the museum's collection was nevertheless based on what was named "Serbian modern art" without a clear, unambiguous and publicly recognizable notion of what exactly Serbian art was, and what separated it from that of other Yugoslavs. The official programmatic statement of the museum was ambiguous as it was stated that: "Serbian art is to be displayed in a wider specter than that of the other Yugoslav nationalities", in spite of the fact that "the museum tends to be Yugoslav in terms of the values shared by non-Serbian artists". ${ }^{27}$

Even more important, however, was yet another register of the museum collection and the narrative, also part of a much wider ideological framework. The museum policy was based on the idea that the museum would eventually become a leading international art centre, which corresponded to Yugoslav régime's constant propensity to represent the country as utterly un-dogmatic and avant-garde in the world politics.

The museum building, erected in 1965, further emphasized this cultural and political imagination. Initially perceived as one of the cutting-edge architectural designs of the time, ${ }^{28}$ it was later described as an "aestheticized place for elegant gatherings [of the communist politicians], a place for new social rituals". ${ }^{29}$ The building of the museum is undoubtedly one of the most influential and praised examples of Yugoslav modernist architecture of the period, superbly designed and executed by Ivan Antić and Jovanka Raspopović. ${ }^{30}$ With its deliberately unorthodox and un-dogmatic visual and spatial crystalline concept, which has been commonly interpreted as straddling architecture and sculpture, the building further reinforced the emancipatory narrative of the museum. Seen as one of the most important works of architecture built in Belgrade and Yugoslavia after the Second World War, both aesthetically superb and far beyond the scope of either Social Realism or standard modernism, it was aimed at representing the country's unorthodox and liberal variant of socialism and its unquestionable cultural and political inclinations. Like the country and the peoples it represented, the museum became a symbol of a distinctive and, at the same time, emancipated Yugoslav identity that was simultaneously conceived as Serbian, Yugoslav and universal, mediating and sharing internationally recognizable values and ideas.

\section{Ibid., p. 8.}

28 Miodrag B. Protić, Nojeva barka SKZ, Beograd, 1992, $571 \mathrm{ff}$.

29 Miloš R. Perović, Srpska arhitektura XX veka: od istoricizma do drugog modernizma, Arhitektonski fakultet, Beograd, 2003, pp. 191-192.

30 See: Milan Popadić, Arhitektura Muzeja savremene umetnosti u Beogradu, in: Nasleđe, 10, 2009, pp. 159-177. The architectural duo Antić-Raspopović were the authors of another museum, the Memorial Museum "Šumarice" in Kragujevac, designed and built between 1968 and 1975. 
On the other hand, the park in which immediate vicinity the museum was built represented an important stratum of the same narrative. Named the Park of Friendship, it exuded a specific ideological aura of mediation which testified both to the concept of Yugoslav "brotherhood and unity" and to the non-aligned policy of Yugoslavia. ${ }^{31}$ Namely, the place was a superb ideological and political arboretum where an extensive variety of trees and saplings were planted by a dazzling number of international political celebrities - from Haile Selassie to Jimmy Carter and Mikhail Gorbachev. In this way, the central idea of the museum narrative was even more amplified, resonating far beyond the museum art collection.

Besides that, the museum was imagined to become a kind of social, cultural and national catalyst, an „instrument of socialization and homogenization" 32 and it was this objective that perhaps represented its key role in the public discourse. The aesthetic values of art were perceived and interpreted as historical phenomena that transcended ethnic and cultural differences and, accordingly, reinforced the sense of belonging to the communion of Yugoslavs as free, interrelated citizens. The museum's ideological agenda was clear: art represented a cohesive force of a rather complex social and ethnic structure of the country, and the museum itself bolstered the mediatory identity of Yugoslavia - both internally, as regards its cultural and national complexity, and externally, in relation to the country's status in the Cold War World realities. At the same time, the Museum of Contemporary Art played an important role in the process of placing Serbian and Yugoslav identities under the sphere of universal values. Not only did, the numerous temporary shows of many international artists exhibiting in the museum, as well as numerous exhibitions that the museum organized abroad, reinforce this remarkable cultural and political process, but also the permanent collection was intended to represent Yugoslav art as integral part of the global artistic scene. During the 1960 s and 1970s, the museum produced not contradictory, but rather complementary narratives spanning from Yugoslav and Serbian, to international. During that period, the museum prepared and facilitated 42 exhibitions of Yugoslav art (sent to various international institutions) and organized and set 114 foreign exhibitions (held in the museum itself) from both Western and Eastern countries. ${ }^{33}$ In the wake of the gradual transformation of the political, ideological and social life in both socialist Serbia and Yugoslavia in the late 1960s and 1970s, such a policy represented an important issue in the Yugoslav ideological restructuring and in the conceptualization of the current idea of multiple identities.

31 See: Ivana Vesković, „Park prijateljstva na Novom Beogradu", Nasleđe, 12, 2011, pp. 203-216.

32 Miodrag B. Protić, "Istorijat Muzeja savremene umetnosti...”, p. 6.

33 Importantly, the first foreign exhibition held in the museum was "Pop-Art in the USA", set in early 1966. See: "1,000 ljudi u muzeju", Večernje novosti, 6. 4. 1966. 


\section{From the Margin to the Center: The Museum of African Art}

Since its opening in 1977, the Museum of African Art has been one of the rare institutions in Europe dedicated to the promotion of art and culture of the African continent beyond standard post-colonial perspective. ${ }^{34}$ Unlike prominent museum institutions exhibiting African art in world centers such as Paris, New York, Washington or London, which were sharply marked by the experience of imperialism and colonialism, the Belgrade museum was a uniquely remarkable and quite incomparable cultural institution. The fact that the entire collection of the museum consisted of artifacts that had been imported from Africa with written permission from the local African governments was in many ways crucial for the museum's narrative and its role in the public discourse. The museum simultaneously represented a new international position of the de-colonized African societies, as well as the Yugoslav role in the Non-Aligned Movement. ${ }^{35}$ The policy of the new museum institution corresponded to one of the central preoccupations of the Yugoslav socialist regime, clearly symbolizing a pinnacle of a two-decade-long cultural politics of balancing between the East-West political divide. In that sense, the museum influenced the ongoing process of collective identity construction in socialist Yugoslavia of the time.

The Museum of African Art was created in order to present and keep the exceptional collection of African art, assembled by two remarkable experts and art collectors - Veda Zagorac Pečar and Dr Zdravko Pečar. Having lived throughout equatorial Africa during the climax of the anti-colonial movement, the Pečars had supported the local African political elites in their efforts of transforming ex-colonies into independent states. They made a huge personal and material effort collecting pieces of immense value, which constituted an extraordinary collection. ${ }^{36}$ Such a collection was recognized by the Yugoslav cultural and political elite of the period, as an instrument of a new practice of social interaction. It promoted the idea of multiculturalism and the mediation of diversities, which would further provide an

34 See: Ana Sladojević, Muzej kao slika sveta, Prostor reprezentacije identiteta i ideologije, doktorska disertacija, Univerzitet umetnosti u Beogradu, Interdisciplinarne studije Teorija umetnosti i medija, Beograd, 2012; Dejan Sretenović, Crno telo, bele maske, Muzej afričke umetnosti, Zbirka Vede i dr Zdravka Pečara, Beograd, 2004.

35 In the divided and constantly fragile world of the Cold War, both super powers and political blocs accepted the idea that the newly liberated African and Asian states should be organized as a separate bloc. Yugoslavia, as a country that refused Soviet domination, but at the same time, never abandoned socialism was perceived as an almost "natural member" of such a Third bloc. Dragan Bogetić, Koreni jugoslovenskog opredeljenja za nesvrstanost, Institut za savremenu istoriju, Beograd, 1990.

36 Veda Pečar, Zdravko Pečar, Muzej afričke umetnosti, Zbirka Vede i dr Zdravka Pečara, Muzej afričke umetnosti, Dečje novine, Beograd, Gornji Milanovac, 1989. 
original framework for innovative cultural practice in multinational Yugoslav society. In that sense, the museum was initially included into a much wider ideological narrative that provided the very foundation of the imagery of socialist Yugoslavia.

In the mid-1970s, the Pečars decided to donate artifacts that they had been collecting over many decades to the City of Belgrade. Although the initial idea was to represent numerous African artifacts as an ethnographical collection, the final decision adopted by the City Council was to transfer the methods of representation from anthropological to art discourse. Everyday objects, numerous musical instruments, ritual masks and jewelry exhibited in the museum created a specific insight into the life of geographically and culturally distant, but politically close Yugoslav allies. ${ }^{37}$

This decision was undoubtedly related to the contemporaneous process of Yugoslav cultural and political imagination. Namely, the insistence of the state and city officials to establish an independent museum of African art was not only the intention but also a constitutive element of Yugoslav self-perception. ${ }^{38}$ With the opening of the museum, citizens were given indirectly, but undoubtedly effective, arguments upholding the ideals of brotherhood among different (Yugoslav) nations and nationalities. At the same time, the specificity of the museum and its collection (in terms of both political and cultural connotations) further reinforced and provided a vivid and operative imagery of Yugoslavia as a "primus inter pares" in the Non-Aligned Movement. The wider cultural and political context in which the museum operated is remarkably significant for comprehending its policy, ambitions and the narrative. Strongly promoting anti-imperialism and the ongoing process of decolonization, Yugoslav officials established close cultural, economical and political ties with the newly liberated countries of Africa and Asia throughout 1970s. The endorsement of their independence was particularly visible in the openness of Yugoslav universities for students coming from different Non-Aligned states. ${ }^{39}$

The ideological significance of the museum, nevertheless, could be recognized in the otherwise highly elaborated comparison between the Yugoslav anti-fascist movement and the socialist revolution during the Second World War, with the actual process of decoloni-

37 Nevertheless, the modes of collecting and evaluating objects in the museum (atemporality of the collection, anonymity of the authors, lack of urban forms of the artistic expressions, etc.) are considered to be an adoption of the colonial narrative in the museum presentation. Ana Sladojević, idib, 119.

38 Dejan Sretenović, Crno telo, bele maske, Muzej afričke umetnosti, Zbirka Vede i dr Zdravka Pečara, Beograd, 2004.

39 Seе: Драгомир Бонџић, Мисао без пасоша, Међународна сарадња Београдског универзитета 1945-1960, Институт за савремену историју, Београд, 2011; Милорад Лазић, „Неки проблеми страних студената на југословенским универзитетима шездесетих година XX века, с посебним освртом на афричке студенте", Годишњак за друштвену историју, вол. 16, 2009-2, 61-78. 
zation in Africa and Asia. The key mission of the museum, as defined by its curatorial staff, was to promote confident political relationships between Yugoslavia and newly liberated African states. ${ }^{40}$ The ideas and values of mediation, tolerance and confidence were, nevertheless, also instrumental for the construction of Yugoslav cultural and political position abroad. The image of Yugoslavs as "staunch and unwavering fighters for freedom" and the position of President Tito as a key figure of both the Non-Aligned Movement and the domestic imagery of "brotherhood and unity" became an important element of constantly developing empathy between cultures and policies, states and nations - which was exactly the background rationale of the museum itself. One of the first photographs of the Non-Aligned Movement founders, taken in July 1956 at the Brioni Summit showing Tito dressed in a white suit between Nehru and Nasser and watching the other two shake hands, could be seen as a highly illustrative symbol of Yugoslavia's coveted status not only among future Non-Aligned countries but, analogously, in the world divided by the opposing political blocks. ${ }^{41}$

The official opening of the museum was part of the events organized during the May festive ceremonies in 1977, which was focused on the celebration of the eighty-fifth birthday of Josip Broz Tito and forty years of his leadership in the Communists League of Yugoslavia. On that occasion, the Major of Belgrade Živorad Kovačević stated:

"The Museum of African Art will develop and revolutionize the cul-
tural awareness of our people, bringing them closer to a more
global understanding of history and culture, man and society. In a
wide range of institutions dedicated to different fields of work and
different periods, from archaeological or medieval, to contempo-
rary art collections, this Museum - both as a collection and a sum
of activities - frees us from our inherited Eurocentric and ethno-
centric beliefs, cultural prejudices and narrow-mindedness, inspir-
ing a deeper and wider outlook on culture, history and mankind." 42

Not only the collection, designed by the architects-curators Slobodan and Jelisaveta Mašić, but also the architecture of the museum, represented a homage to African culture and also to Yugoslavia as its prime supporter and protector. The museum building was designed in 1973-1976 and built for the purpose in 1977. Despite

40 Veda Pečar, Zdravko Pečar, Muzej afričke umetnosti, Zbirka Vede i dr Zdravka Pečara, Muzej afričke umetnosti, Dečje novine, Beograd, Gornji Milanovac, 1989; Dejan Sretenović, Crno telo, bele maske, Muzej afričke umetnosti, Zbirka Vede i dr Zdravka Pečara, Beograd, 2004.

41 Olga Manojlović Pintar, "On gifts and gift giving", The Tito Effect, Charisma as political legitimacy, Museum of Yugoslav History, Belgrade, 2009.

42 http://www.museumofafricanart.org/en/about-the-museum/mission.html 
the fact that the edifice was renovated in the tradition of the Western colonial discourse and the "authentic" representation of indigenous architecture, the context of the representation of African culture was rather different. The image of "authenticity" was transferred to a modern architectural language, akin to contemporary brutalism, signifying the Yugoslav symbolical attempts to revitalize Africa by socialism as well as by a distinct, Yugoslav model of national unity. Thus the museum epitomized a rather "Titoist" political figure of Africa which "did not represent a figure of an absolute other, the one that is excluded and detached, but a figure of a partner, of a 'younger brother' marching to socialism." 43

Various masks and sculptures have represented the most important part of the museum's collection. Other exhibited objects illustrated everyday life in the different African regions including specific musical instruments, textiles, pottery and ritual ceramics, woodcarvings, bronze sculptures and soapstone figurines. Sorted by the materials from which the objects were made, these collections mixed common objects and artistic artifacts thus erasing the artificially established divide between everyday life and high art. Thus, the museum vividly represented and materialized the idea of eradicating all sorts of boundaries - those between the margin and the center, between the different nations, states and cultures, between the "civilized" and the "primitive". The same emancipatory agenda stood at the very heart of the peculiarly Yugoslav concept of identity, which simultaneously encompassed diverse cultures, nations and traditions. However, the museum's nominal anti-colonial narrative became obvious only with the passage of time, after it developed into "the museum with history" - the institution holding the "memory on previous representations, which modeled not only the museum, but also the perception of the world of its visitors". ${ }^{44}$

\section{Conclusion}

Ever since 1989 and the proclamation of the end of history, in public space socialism was represented as a culturally inferior "other". As theorist and psychoanalyst Boris Buden has put it: "The historical project of the universal emancipation (i.e. communism) is transferred into a particular cultural identity and presented as a traumatic experience of the cultural difference." 45 The new present created after the fall of the Berlin Wall acquired the new interpretations of the past, which blurred historical frameworks existing for decades. ${ }^{46}$ Some of

43 Dejan Sretenović, op. cit., p. 26.

44 Ana Sladojveć, ibid., p. 170.

45 Boris Buden, "U cipelama komunizma, Nekoliko napomena o mehanizmu postkomunističke normalizacije", Up \& underground, Art dossier, 2004, no. 7/8, pp. 34-39.

46 See: Muzeji kao mesta pomirenja, Zbornik radova sa 8. kolokvijuma Međunarodne 
the most important institutions actively constructing post-socialist societies were museums, as direct interpreters and exhibitors of the past. Mushrooming all over the former Eastern Europe, the new museum institutions and exhibitions clearly testified to a need to create a direct and unambiguous association, i.e. stereotype of socialism. However, they spoke more about the time in which they were created then about the one they wanted to represent. In the same manner, the museum institutions conceptualized, organized and functioning during the period of socialism represented paradigms and the illustrative examples of another representative politics and its impact on the collective identities creation.

Established during the 1960 s and 1970 s three Belgrade museums created in for them specially designed buildings, (The Museum of the $25^{\text {th }}$ of May, The Museum of the Contemporary Art, The Museum of African Art), actively created the specific identity of socialist Yugoslavia and its citizens. Three pillars of Yugoslav society defined through self-management, the Non-Aligned Movement and the ideology of "brotherhood and unity" were strengthened and affirmed through those museums policies and exhibitions. ${ }^{47}$

asocijacije istorijskih muzeja, Istorijski muzej Srbije, Beograd, 2010; Ljiljana Gavrilović, Muzeji i granice moći, Biblioteka XX vek, Beograd, 2011.

47 The fourth museum which was projected and designed in the same period by the architect Ivan Štraus, the Aeronautical Museum, did not have a chance to actively participate in the identity making process being opened only in 1989. 


\section{Резиме}

Др Олга Манојловић Пинтар Др Александар Игњатовић

\section{Катализатори сложених идентитета: три београдска музеја у социјалистичкој Југославији}

Кључне речи: Музеј 25 мај, Музеј савремене уметности, Музеј афричке уметности, социјалистичка Југославија, идентитет

Музеј „25. мај”, Музеј савремене уметности и Музеј афричке уметности, који су осмишљени и подигнути у Београду у периоду од почетка шездесетих до краја седамдесетих година 20. века, представљали су парадигматске примере креирања и ширења новог концепта идентитета у јавном простору социјалистичке Југославије. Процес друштвеног структурирања, политичке легитимизације, али и националне идентификације је дефинисан између осталог и кроз изложбене политике наведених музејских институција. Њихов значај у стварању културне политике социјалистичке Југославије у време хладног рата је сведочио о динамичном друштву које је карактерисала стална компетиција бројних социјалних, политичких и културних агената. Различите начине стварања и приказивања историјских наратива присутне у програмским концептима музејских институција могуће је сажети у две парадигме. Прва, условно препозната као: сталност и дуговечност, дефинисала је представу изузетности и јединствености југословенског друштва стварајући историјске континуитете кроз време и простор. Друга, која је сажета у појмовима: повезивање и премошћавање, у јавном простору је идеолошки и политички обједињавала и инструментализовала различите културне и политичке реалитете. Излажући селектовано културно наслеђе три разматрана музеја су активно учествовала у идеолошком конструисању идентитета и у процесу „упросторавања" политичке моћи, снажећи визију југословенског друштва као јединственог културног и политичког медијатора. 